\title{
Nonobstructive azoospermia, when we can find spermatozoa, is FSH as a marker of succes?
}

\author{
A. Khelaia, orcid: 0000-0002-3163-4984, e-mail: alekoxelaia@gmail.com
} National Center of Urology, Tbilisi, Georgia

Keywords:

azoospermia, infertility, embryologist

\section{For citation:}

ДСТУ 8302 2015:

Khelaia A. Nonobstructive azoospermia, when we can find spermatozoa, is FSH as a marker of succes? Урологія. 2021. T. 25, № 2. C. 102-106. DOI: $10.26641 /$ 2307-5279.25.2.2021.238226.

APA:

Khelaia, A. (2021). Nonobstructive azoospermia, when we can find spermatozoa, is FSH as a marker of succes? Urologiya, 25(2), 102-106. DOI: $10.26641 / 2307-5279.25 .2 .2021$. 238226

\section{INTRODUCTION Вступ}

Azoospermia is the absence of spermatozoa in ejaculate even after semen centrifugation at least two times. Azoospermia due to spermatogenic fauilure - non-obstructive azoospermia (NOA) observed in $1 \%$ of population and in $10-15 \%$ of infertile men. Testicular sperm extraction (TESE) and intracytoplasmic sperm injection (ICSI) was devised by Palermo et al. in 1992 and first pregnancy was reported in 1993 (1). This approach revolutionized treatment in this cohort of infertile men. Testicular spermatozoa can be retrieved in most men with NOA because of the existence of isolated foci of active spermatogenesis. Predictive factors for the presence of spermatozoa in testis are still under debate. These factors are: follicle -stimulating hormone (FSH), inhibin B, testicular volume, testicular histopatology, protamine PCR ratio, Y chromosome deletions and others (2). FSH play an important role in regulating spermatogenesis. FSH increases spermatogonial number and maturation of spermatocytes, including meiosis, but it is unable to complete spermatogenesis. In cases of azoospermia due to severely damaged germ cells, serum FSH levels are usually elevated. So, serum FSH levels reflect the state of seminiferous epitelium (3).

\section{MATERIALS AND METHODS Матеріали і методи дослідження}

We performed retrospective review of 664 patients with azoospermia and 429 cases of TESA were done 
from September 2014. In study analysis we included only nonobstructive azoospermic (NOA) cases. All cases, suspected as obstructive azoospermia, were excluded from our study. In NOA 371 men (mean age 31.8 years) FSH level was detected in 368 cases. Mean serum FSH was 17,27 mU/ml (range 0,2-102,51 $\mathrm{mU} / \mathrm{ml})$. In 17 cases Klinefelter syndrome was detected, with mean serum FSH level $48 \mathrm{mU} / \mathrm{ml}$ (range 20,6-102,51 mU/ml).

Finally, 337 men with NOA and normal karyotype (no Klinefelter syndrome and no $\mathrm{Y}$ chromosome deletions) after testicular sperm extraction were included in our study. The main method of testicular sperm extraction was percutaneous testicular sperm aspiration (TESA) with 19 G "butterfly" needle and vacuum applied with $10 \mathrm{ml}$ medium in syringe. Procedure was done under general sedation. Multiple passes were performed in random way throughout the testis (uni or bilaterally) until tissue was visible in needle tube. The specimen is split and send in media for live sperm analysis by embryologist (Fig. 1) and in the same way was sent to standard histology in Bouins solution. First time in Georgia histological evaluation of testicular tissue samples in NOA was done (2014 year).

In operated group of men mean FSH level was $16,33 \mathrm{mU} / \mathrm{ml}$ (range $0,2-42,14 \mathrm{mU} / \mathrm{ml}$ ).

\section{RESULTS AND DISCUSSION Результати та їх обговорення}

Sperm retrieval rate (SRR) was $43.3 \%$, in 148 cases from 337. In men were sperm was found mean serum FSH was $9,7 \mathrm{mU} / \mathrm{ml}$ (range 0,2$40,1 \mathrm{mU} / \mathrm{ml}$ ). At the same time in cases were sperm wasn't found mean serum FSH was $16,4 \mathrm{mU} / \mathrm{ml}$ (range 6,0-42,3 $\mathrm{mU} / \mathrm{ml}$ ) (Fig. 2).

According serum FSH levels we divided our men in three groups: FSH $<10 \mathrm{mU} / \mathrm{ml}, 10-15 \mathrm{mU} / \mathrm{ml}$ and $>15 \mathrm{mU} / \mathrm{ml}$. We tried to evaluated SRR in accordance serum FSH level and find significant difference. In 117 men with FSH $<10 \mathrm{mU} / \mathrm{ml}$ SRR was $66 \%$ (in 77 cases), in 89 men which FSH was $10-15 \mathrm{mU} / \mathrm{ml} \mathrm{SRR}$ was $27 \%$ and finally SRR was $35 \%$ when FSH was $>15 \mathrm{mU} / \mathrm{ml}$ (45 cases from 131) (Fig. 3).

In our cohort of cases with random percutaneous testicular sperm aspiration (TESA) SRR rate was $43.3 \%$. However SRR less than $50 \%$ were observed in larger series. Ramasamy et al. in 460 cases find SRR by conventional TESE $32 \%$ (4). TESA has been known for decades as a simple, minimally invasive approach for sperm retrieval. Of course today "gold" standard for NOA is a micro-TESE, which was proposed by Peter N. Schlegel, but SRR as we can see again from

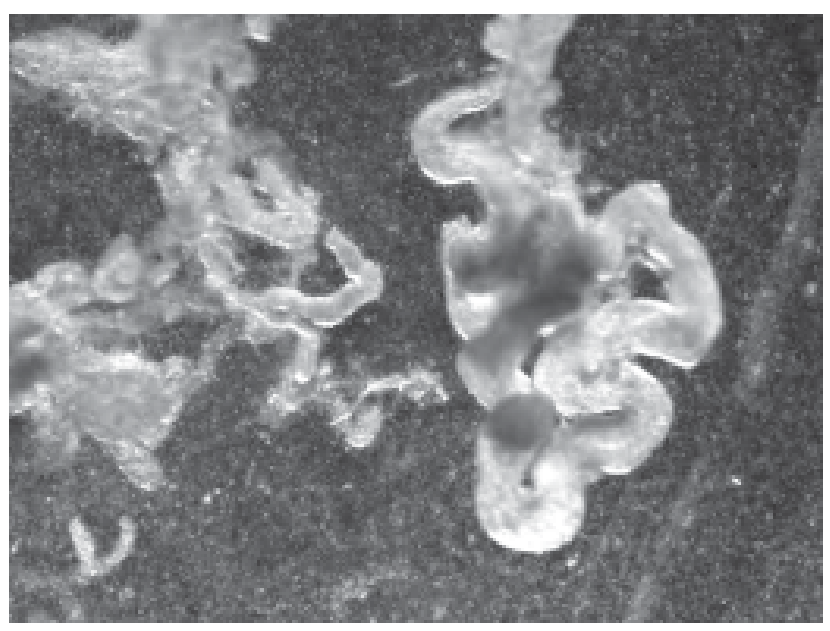

FIGURE 1. Large tubules have a high possibility of including full spermatogenesis, thin tubules contain only Sertoli cells without germ cells or total hyalinosis

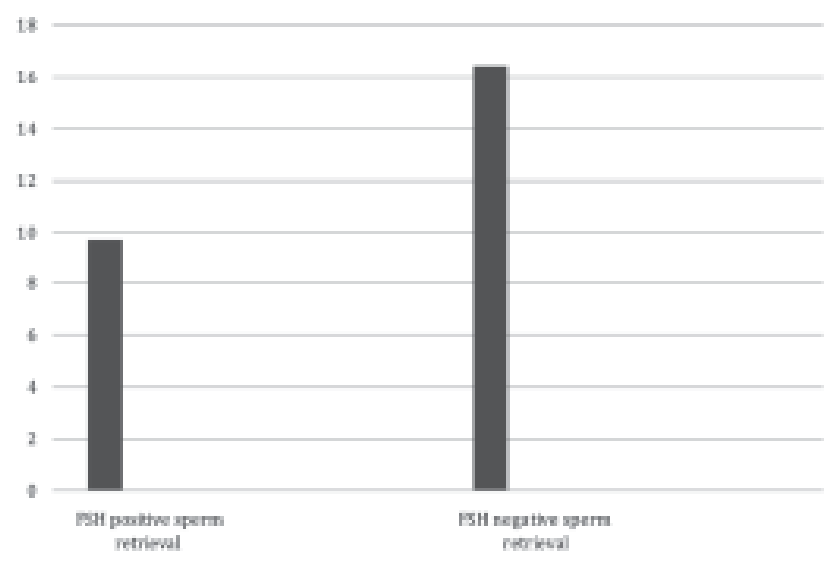

FIGURE 2. Sperm retrieval rates and serum FSH levels

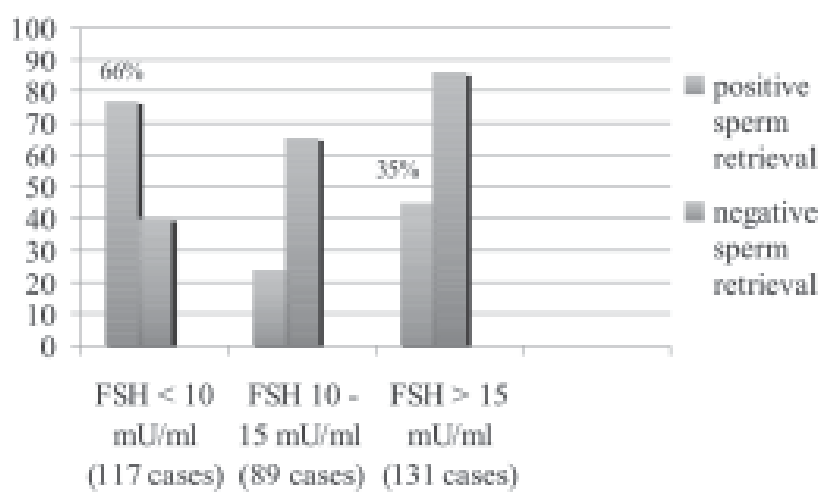

FIGURE 3. Sperm retrieval rates stratified by serum FSH level division

Ramasamy study was $57 \%$. In our modification TESA with multiple random samples taken from different sites of the testis have higher SRR than men with a single biopsy sample taken. At the same time conventional TESE - open biopsy with removal of large samples of testicular tissue could lead to testicular atrophy. However Christian et al. find in men after 
failed TESA a limited chance of SRR using microTESE (5). In our experience after failed TESA conventional open - TESE was also unsuccessful (data not included in this study).

But what is the main predictive factor for sperm retrieval success? Surgical technique or embryologist experience? It is very debate question and still today there is no complete answer. May be very expensive laboratory evaluation before biopsy, most of them only experimental and far away from routine clinical practice. The chance of Klinefelter syndrome is $10-15 \%$ in cases of NOA and severe oligospermia. This investigation can be done in Georgia. But Y-chromosomal microdeletions PCR detection, which can be find in $4-12 \%$ of men with azooapermia, is not possible to do in our country. In our practice we sent blood samples to special centers abroad to exclude AZFa, $\mathrm{AZFb}$ and $\mathrm{AZFc}$ deletions. For men with complete $\mathrm{AZFa}$ or $\mathrm{AZFb}$ deletions testicular biopsy is not recommended ( $0 \%$ of SRR), only in AZFc men we can find spermtatozoon and this genetic disorder will be obligatorily transmitted to the son (6). In all our cases we excluded Y-chromosomal microdeletions. And what about FSH? It is easy to done, it is very important player in spermatogenesis. According to our results the best FSH level for SRR is $<10 \mathrm{mU} / \mathrm{ml}-\mathrm{SRR}$ $66 \%$, the worst $10-15 \mathrm{mU} / \mathrm{ml}$ with SRR $27 \%$. On the other hand even in cases of FSH $40 \mathrm{mU} / \mathrm{ml}$ sperm retrieval is possible (6). We try to explain this phenomen. Our important finding is in agreement with Peter N. Schlegel team study. In their study men with FSH $10-15 \mathrm{mU} / \mathrm{ml}$ and testicular volume $>15 \mathrm{cc}$ had SRR $6,7 \%$ (7). Explanation of this phenomen is histological status within the testis. Sertoli cell-only syndrome men, even with normal or moderately elevation (up to $15 \mathrm{mU} / \mathrm{ml}$ ) of FSH level may have a larger number of Sertoli cells with normal testicular volume. This combination provides feedback to the hypothalamic-pituitary-gonadal axis (HPG) which suppress FSH secretion. As the result we didn't find sperm in such cases. This situation is very closed to maturation arrest (Fig. 4).

Those men with higher FSH may represent increased heterogeneity in spermatogenesis and a better possibility to find spermatozoon. On the other hand, some men with lower FSH levels $(<10 \mathrm{mU} / \mathrm{ml})$ may have more feedback to the HPG axis as a result of complete spermatogenesis. So, at this moment we come to crucial point of discussion - histomorphology within the testis in NOA. For us this is a main feedback for sperm retrieval and in each case of positive or negative results we try to find explanation in morphological situation within testis. We have preliminary results and study in this way in progress.

At the same time, we make embryologist personal assessment (EPA). In our pilot EPA we cover only

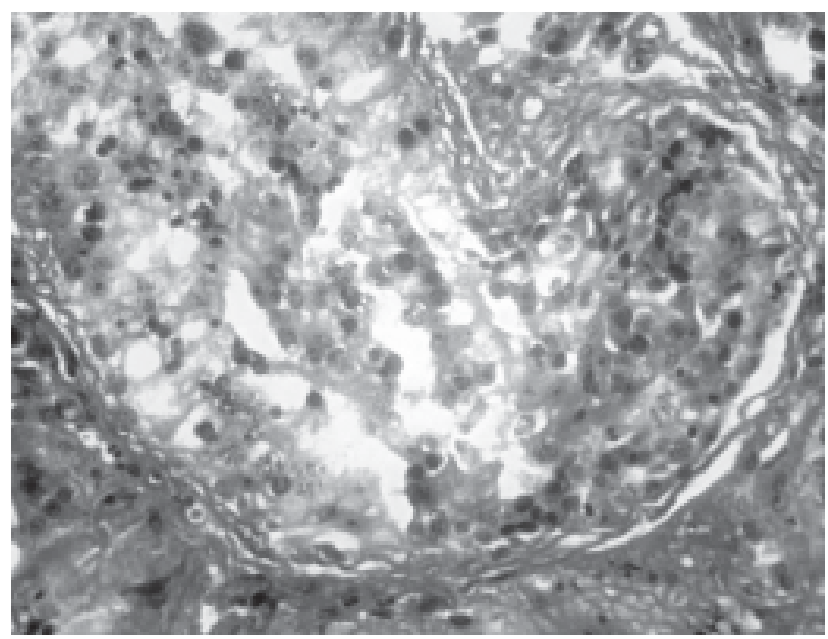

FIGURE 4. Maturation arrest, absence of round spermatids. NOA man, FSH 6,5 mU/ml

one selected month - 2019 May, during this month 11 TESA for NOA were done - SRR was $37 \%$. We compare this data with SRR results when tissue assessment was done by one embryologist (EMGT) - SRR was $76 \%$. This data is quite comparable to micro - TESE results (data not published). Micro TESE is proposed as a "gold standard" for successful sperm retrieval rate, sure in some difficult case it's best option. But in our pilot EPA study we try to show embryologist crucial role in tissue assessment after TESA.

\section{CONCLUSIONS Висновки}

The development of ICSI revolutionized management of azoospermia. In our practice we advised TESA as a first step and FSH can predict the success. TESA it is not only a diagnostic procedure to define the level of spermatogenesis, but also a therapeutic technique to retrieve sperm for ICSI. Also, in cases of negative results after TESA and hypospermatogenesis by histopatology (Fig. 5) we advised re - TESA after 3-6 months. Also, we advocate embryologist crucial role in tissue assessment after TESA.

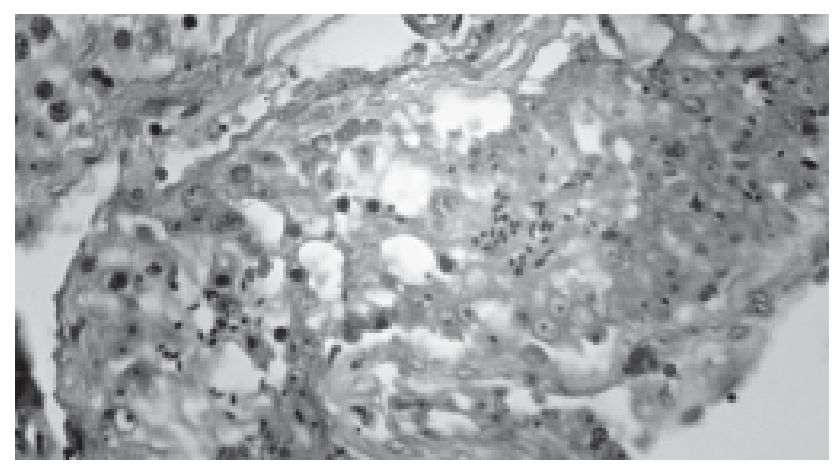

FIGURE 5. Hypospermatogenesis with consistent proportion of germ cells at each stage of development, including spermatozoids 


\section{СПИСОК ЛІТЕРАТУРИ References}

1. Palermo G. et al. Pregnancies after intracytoplasmic injection of single spermatozoon into an oocyte. Lancet. 1992. Vol. 340. P. 17-18.

2. Boitrelle F. et al. A predictive score for testicular sperm extraction quality and surgical ICSI outcome in non-obstructive azoospermia: a retrospective study. Hum Reprod. 2011. Vol. 26. P. 3215-3221.

3. Tilbrook A. et al. Negative feedback regulation of the secretion and actions of gonadotropin-releasing hormone in males. Biol Reprod. 2001. Vol. 64. P. 735-742.

4. Ramasamy R. et al. Structural and functional changes to the testis after conventional versus microdissection testicular sperm extraction. Urology. 2005. Vol. 65. P. 1190-1194.

5. Christian F.S. et al. 30 th EAU congress abstract book No. 290. Madrid, Spain.

6. Ramasamy R. et al. High serum FSH levels in men with nonobstructive azoospermia does not affect success of microdissection testicular sperm extraction. Fertil Steril. 2009. Vol. 92. P. 590-593.

7. Berookhim B.M. et al. Microdisection testicular sperm extraction in men with Sertoli cell - only testicular histology. Fertil Steril. 2014. Vol. 102, No. 5. P. 1282-1286.

\section{PЕФЕРАT}

Необструктивна азооспермія: коли ми можемо знайти сперматозоїд i чи є ФСГ маркером успіху?

\section{О. Хелая}

Азооспермія - це відсутність сперматозоїдів в еякуляті навіть після центрифугування сперми не менше двох разів. Азооспермія через сперматогенну недостатність - необструктивна азооспермія (NOA), яка спостерігається у $1 \%$ населення і у 10-15\% безплідних чоловіків. Фактори, що дозволяють прогнозувати наявність сперматозоїдів в яєчках, все ще обговорюються. Розробка İKCI் зробила революцію в лікуванні азооспермії. У нашій практиці ми рекомендували TESA як перший крок, і ФСГ як предиктор успіху. Відповідно до рівня ФСГ в сироватці ми розділили наших чоловіків на три групи: ФСГ <10 мед/мл, 10-15 мед/мл i $>15$ мед/мл. Ми спробували оцінити SRR відповідно до рівня ФСГ в сироватці і знайти значну різницю. У 117 чоловіків з ФСГ $<10$ мед/мл SRR становив $66 \%$ (в 77 випадках), у 89 чоловіків, у яких ФСГ становив 10-15 мед/мл, швидкість вилучення

\section{REFERENCES \\ Список літератури}

1. Palermo, G., et al. (1992). Pregnancies after intracytoplasmic injection of single spermatozoon into an oocyte. Lancet, 340, 17-18.

2. Boitrelle, F., et al. (2011). A predictive score for testicular sperm extraction quality and surgical ICSI outcome in non-obstructive azoospermia: a retrospective study. Hum Reprod, 26, 3215-3221.

3. Tilbrook, A., et al. (2001). Negative feedback regulation of the secretion and actions of gonadotropin-releasing hormone in males. Biol Reprod., 64, 735-742.

4. Ramasamy, R., et al. (2005). Structural and functional changes to the testis after conventional versus microdissection testicular sperm extraction. Urology, 65, 1190-1194.

5. Christian, F.S., et al. 30 th EAU congress abstract book No. 290. Madrid, Spain.

6. Ramasamy, R., et al. (2009). High serum FSH levels in men with nonobstructive azoospermia does not affect success of microdissection testicular sperm extraction. Fertil Steril., 92, 590-593.

7. Berookhim, B.M., et al. (2014). Microdisection testicular sperm extraction in men with Sertoli cell - only testicular histology. Fertil Steril., 102, 5, 1282-1286.

\section{PEФЕРAT}

Необструктивная азооспермия: когда мы можем найти сперматозоид и является ли ФСГ маркером успеха?

\section{А. Хелая}

Азооспермия - это отсутствие сперматозоидов в эякуляте даже после центрифугирования спермы не менее двух раз. Азооспермия из-за сперматогенной недостаточности - необструктивная азооспермия (NOA), наблюдаемая у $1 \%$ населения и у $10-15 \%$ бесплодных мужчин. Факторы, позволяющие прогнозировать наличие сперматозоидов в яичках, все еще обсуждаются. Разработка ИКСИ произвела революцию в лечении азооспермии. В нашей практике мы рекомендовали TESA в качестве первого шага, и ФСГ как предиктор успеха. В соответствии с уровнем ФСГ в сыворотке мы разделили наших мужчин на три группы: ФСГ <10 мЕд/мл, 10-15 мЕд/мл и > 15 мЕд/мл. Мы попытались оценить SRR в соответствии с уровнем ФСГ в сыворотке и найти значительную разницу. У 117 мужчин с ФСГ $<10$ мЕд/мл SRR составлял 66\% (в 77 случаях), у 89 мужчин, у которых ФСГ составлял 
сперми (SRR) становила 27\% i, нарешті, SRR становив 35\%, коли ФСГ був> 15 МО/мл. (45 випадків з 131). У той же час ми проводимо особисту оцінку ембріолога (ЕРА) і намагаємося показати вирішальну роль ембріолога в оцінці тканин після TESA. Ще один важливий момент для обговорення - гістоморфологія яєчка при NOA і показання для повторного проведення TESA через 3-6 місяців.

Ключові слова: азооспермія, безпліддя, ембріолог.
10-15 мЕд/мл, скорость извлечения спермы (SRR) составляла $27 \%$ и, наконец, SRR составлял 35\%, когда ФСГ был $>15$ мЕ/мл (45 случаев из 131). В то же время мы проводим личную оценку эмбриолога (ЕРА) и пытаемся показать решающую роль эмбриолога в оценке тканей после TESA. Еще один важный момент для обсуждения - гистоморфология яичка при NOA и показания для повторного проведения TESA через 3-6 месяцев.

Ключевые слова: азооспермия, бесплодие, эмбриолог. 